\title{
EFFECTS OF ORGANIC MANURES AND THEIR COMBINATION WITH UREA ON SWEET PEPPER PRODUCTION IN THE MID-HILLS
}

\author{
Suresh Ghimire ${ }^{1}$, Santa M. Shakya ${ }^{2}$, Arvind Srivastava ${ }^{3}$
}

\begin{abstract}
Using excessive chemical fertilizers to combat increasing challenges for food has been creating a serious threat to the environment. To address this contemporary problem field experiments were carried out during March-July, 2010 and February-August, 2011 to evaluate the effect of organic manures and their combination with urea on production of sweet pepper in a randomized complete block design. Farmyard manure, goat manure, vermicompost, their combination with urea, and inorganic fertilizers alone were used as treatments based on fulfillment of required nitrogen $(150 \mathrm{Kg} / \mathrm{ha})$ for the crop. The results showed that application of FYM-50\%+urea-50\% gave the highest fruit set $(45.7 \%)$ and took least number of days (49.67 days) to first flowering. Weight per fruit was the highest $(98.30 \mathrm{~g})$ with $\mathrm{FYM}-50 \%+u r e a-50 \%$ followed by vermicompost-100\% (94.52 g). The highest fruit yield (13.53 t/ha) was recorded with FYM-50\%+urea-50\% followed by goat manure$100 \%$ (11.95 t/ha), both being at par. Physiological weight loss was the highest (16.4\%) with inorganic fertilizers and was the lowest (6.7\%) with goat manure $100 \%$.
\end{abstract}

Keywords: Capsicum; nitrogen; organic; substitution; yield

\section{INTRODUCTION}

Sweet pepper (Capsicum annuumL.) is commonly known as bell pepper, capsicum or green pepper. Annual world production of chilli and bell pepper (green) in the year 2009 was 28.07 million metric tons from an area of 1.81 million ha where China was the major producer with an area of 0.66 million ha with a production of 14.52 million tons (FAO, 2011). CBS (2010) reported that the total area in Nepal under sweet pepper in 2010 was 530 ha with production of 3,497 mt (6.59 t/ha). Sweet pepper is a high value crop in Nepal and has high market price. This is attributed to the heavy demand from the urban consumers. To meet the increasing demand use of excessive inorganic fertilizers is becoming a common practice as a means of raising the productivity. This has created negative effects on human health and environment.

Long-term studies on various crops indicated that the balanced use of NPK fertilizer could not maintain the higher yields over years because of emergence of secondary and micronutrient deficiencies and deterioration of soil physical properties. Use of organic manures alone cannot fulfill the crop nutrient requirements (Deore et al., 2010). Bokhtiar et al. (2008) reported that organic manures, when applied with chemical fertilizers gave better yield than each

\footnotetext{
1 Horticulture Development Officer, District Agriculture Development Office, Bhaktapur, Cell: 9847191750, Email: sureshghimire19@hotmail.com

2 Professor, Institute of Agriculture and Animal Science, Chitwan, Nepal.

${ }^{3}$ Assoc. Professor, Institute of Agriculture and Animal Science, Chitwan, Nepal.
} 
alone. Hence there is urgent need to promote the use of improved organic manures.

\section{OBJECTIVE}

In tune with the contemporary problem; increased demand of food and a threat to human health and environment due to excessive use of chemicals, the present study was carried out to assess the effect of different types of organic manures and their combination with urea on the growth, yield and quality of sweet pepper.

\section{MATERIALS AND METHODS}

Two field experiments were carried out in the same season of two successive years. In the experiment carried out at Dovan-4, Palpa, there were seven treatments with four replications. The experiment was conducted in a randomized complete block design. Thus, there were altogether 28 plots. Each experimental plot had a net area of $3.24 \mathrm{~m}^{2}$. Net experimental area was $90.72 \mathrm{~m}^{2}$. Row to row spacing was $60 \mathrm{~cm}$ and the space between two plants was $45 \mathrm{~cm}$. There were five rows per plot accommodating six plants per row. There were altogether 30 plants plot-1 with 12 observational plants and 18 border plants. There was $50 \mathrm{~cm}$ space between two plots and space of $1 \mathrm{~m}$ was kept between the blocks.

The experiment at Dovan-4, Palpa was started on $28^{\text {th }}$ March, 2010 when seeds were sown in a nursery bed. The data from the experiment were recorded only up to 60 days after transplanting of the seedlings after which further data could not be recorded because the plots were heavily damaged due to unusual heavy and continuous rainfall. Though, reliable conclusion couldn't be drawn from incomplete data of this experiment, some data are presented here in order to show the trend. Furthermore, another experiment was conducted at Nagarkot-1, Bhaktapur to take all the required data. Nagarkot-1, Bhaktapur was selected because it has a climate similar to the experimental site in Palpa.

In the experiment carried out at Nagarkot-1, Bhaktapur, there were 7 treatments but only 3 replications because there was limitation of land due to hilly terrain. Thus, there were altogether 21 plots. Individual net plot area was the same as that of the Dovan-4, Palpa experiment. Net experimental area was $68.04 \mathrm{~m}^{2}$. Plant-to-plant spacing was same as that of the experiment conducted in Palpa.

The treatments consisted of full dose of nitrogen through sole application of FYM, goat manure and vermicompost, half dose of nitrogen through these manures (individually) + half dose through urea, and recommended dose of chemical fertilizers (150:75:50 NPK Kg/ha) as control (Sunitha, 2007). All the treatments were based on the fulfillment of the required nitrogen to the crop $(150 \mathrm{~kg} / \mathrm{ha})$. The quantity of organic manures was calculated based on nitrogen content of the organic manures tested in the laboratory. Though amount of $\mathrm{P}_{2} \mathrm{O}_{5}$ and $\mathrm{K}_{2} \mathrm{O}$ was not considered in all the treatments except the control one, their requirement was exceeded when manures were applied considering nitrogen requirement in all the cases. All the organic manures with their full dose, half dose of mineral nitrogen, 
total dose of phosphorus and total dose of potash were applied according to treatment requirement at final land preparation. Remaining amount of nitrogen was top dressed at one month after transplantation. Mineral NPK was applied through urea, diammonium phosphate (DAP) and murate of potash (MOP). Data were collected for vegetative and yield attributing characters and quality parameters. Analysis of variance (ANOVA) was used to test for differences among the treatments and means were separated using least significance difference (LSD).

\section{RESULTS AND DISCUSSIONS}

\section{VEGETATIVE CHARACTERS}

In the first experiment, at earlier stage of growth, there was no significant effect of the treatments. But at later stage (at 60 days after transplanting) application of FYM 50\% + urea 50\% significantly increased the plant height $(33.02 \mathrm{~cm})$, number of leaves per plant (61.20). The number of primary branches (4.267), fresh shoot weight (193.5 g) was also significantly increased with FYM 50\% + urea 50\% followed by goat manure $50 \%$ + urea $50 \%$. Application of inorganic fertilizers alone resulted into significantly lower vegetative growth at later stage of crop growth (Table 1).

Table 1. Effect of different nitrogen sources on plant growth of sweet pepper California Wonder at 60 DAT, Dovan, Palpa, 2010

\begin{tabular}{lllll}
\hline Treatments & $\begin{array}{l}\text { Plant height } \\
(\mathrm{cm})\end{array}$ & No. of leaves/plant & $\begin{array}{l}\text { No. of primary } \\
\text { branches }\end{array}$ & Fresh shoot weight $(\mathrm{g})$ \\
\hline FYM100\% & $29.92 \mathrm{bc}$ & $54.42 \mathrm{bc}$ & $2.867 \mathrm{c}$ & $176.5 \mathrm{bc}$ \\
FYM50\%+urea50\% & $33.02 \mathrm{ab}$ & $61.20 \mathrm{a}$ & $4.267 \mathrm{a}$ & $193.5 \mathrm{a}$ \\
GM100\% & $26.01 \mathrm{~d}$ & $55.13 \mathrm{bc}$ & $2.900 \mathrm{c}$ & $179.2 \mathrm{bc}$ \\
GM50\%+urea50\% & $27.51 \mathrm{~cd}$ & $58.58 \mathrm{abc}$ & $3.933 \mathrm{ab}$ & $188.1 \mathrm{ab}$ \\
VC 100\% & $27.16 \mathrm{~cd}$ & $53.38 \mathrm{c}$ & $3.600 \mathrm{~b}$ & $175.1 \mathrm{c}$ \\
VC 50\%+urea50\% & $30.70 \mathrm{ab}$ & $58.95 \mathrm{ab}$ & $4.067 \mathrm{ab}$ & $172.8 \mathrm{c}$ \\
NPKchemicals & $26.07 \mathrm{~d}$ & $56.83 \mathrm{abc}$ & $2.933 \mathrm{c}$ & $182.1 \mathrm{bc}$ \\
LSD(P= 0.05) & $3.844^{* *}$ & $4.87^{*}$ & $0.5187^{* *}$ & $10.77^{* *}$ \\
SEm & 1.293 & 1.641 & 0.1683 & 3.626 \\
CV\% & 9.04 & 5.76 & 8.29 & 4.00 \\
\hline
\end{tabular}

FYM100\% : Full nitrogen through FYM, FYM50\%+urea50\% : Half nitrogen through FYM + half nitrogen through urea, GM100\% : Full nitrogen through goat manure, GM50\%+ urea50\% : Half nitrogen through goat manure + half nitrogen through urea, VC100\% : Full nitrogen through vermicompost, VC50\%+urea50\%: Half nitrogen through vermicompost + half nitrogen through urea,NPK Chemicals:recommended dose of chemicalfertilizers(150:75:50 NPK kg/ha)

*: Significant at 0.05 probability level, ${ }^{* *}$ : Significant at 0.01 probability level

In the second experiment, at earlier stage of growth, there was no significant effect of the treatments. But at later stage (at 90 days after transplanting) application of FYM 50\% + urea 50\% significantly increased the plant height $(70.84$ $\mathrm{cm})$, stem diameter $(1.77 \mathrm{~cm})$, number of leaves per plant $(171.66)$ followed by 
goat manure $100 \%$. The number of primary branches $(4.73)$, fresh shoot weight (268.30 g) was also significantly increased with FYM $50 \%$ + urea $50 \%$ followed by goat manure $50 \%+$ urea $50 \%$. Application of inorganic fertilizers alone resulted into significantly lower vegetative growth at the later stage of crop growth (Table 2).

Damke et al. (1988) also observed greater plant height $(60.3 \mathrm{~cm})$ of chilli with application of FYM 9 t/ha +50 kg inorganic nitrogen. Surlekov and Rankov (1989) recorded greater number of leaves per plant in chilli with the application of FYM and inorganic nitrogen. Renuka and Ravisankar (2001) reported that integrated application of FYM (15 t/ha) with nitrogen $(120 \mathrm{~kg} / \mathrm{ha})$ resulted into significantly higher number of branches (3.66).

Table 2. Effect of different organic manures and their combination with urea lanting

\begin{tabular}{|c|c|c|c|c|c|}
\hline Treatments & $\begin{array}{l}\text { Plant height } \\
(\mathrm{cm})\end{array}$ & $\begin{array}{l}\text { Stem diameter } \\
(\mathrm{cm})\end{array}$ & No. of leaves/plant & $\begin{array}{l}\text { No. of primary } \\
\text { branches }\end{array}$ & $\begin{array}{l}\text { Fresh shoot } \\
\text { weight (g) }\end{array}$ \\
\hline FYM100\% & $68.82 \mathrm{ab}$ & $1.517 \mathrm{c}$ & 145.20abc & $3.083 \mathrm{~d}$ & $242.0 \mathrm{bc}$ \\
\hline FYM50\%+urea50\% & $70.84 a$ & $1.773 a$ & $171.66 a$ & $4.733 a$ & $268.3 a$ \\
\hline GM100\% & $69.93 a$ & $1.710 a b$ & $160.46 a b$ & $3.250 \mathrm{~cd}$ & $246.5 b c$ \\
\hline GM50\%+urea50\% & 67.70abc & $1.537 \mathrm{c}$ & $124.20 \mathrm{bcd}$ & 4.333ab & $256.8 \mathrm{ab}$ \\
\hline VC $100 \%$ & $64.06 \mathrm{c}$ & $1.560 \mathrm{bc}$ & $127.26 \mathrm{bcd}$ & $3.800 \mathrm{ab}$ & $237.7 \mathrm{bc}$ \\
\hline VC 50\%+urea $50 \%$ & $65.23 \mathrm{bc}$ & $1.567 \mathrm{bc}$ & $121.86 \mathrm{~cd}$ & $4.400 \mathrm{ab}$ & $234.3 c$ \\
\hline NPKchemicals & $63.72 c$ & $1.480 \mathrm{C}$ & $105.46 d$ & $3.600 \mathrm{~cd}$ & 245.7bc \\
\hline $\operatorname{LSD}(P=0.05)$ & $3.081^{* *}$ & $0.1488^{*}$ & $33.83^{*}$ & $0.6033^{* *}$ & $17.98^{*}$ \\
\hline SEm & 1.234 & 0.0483 & 10.98 & 0.1958 & 5.836 \\
\hline CV\% & 3.18 & 5.38 & 13.92 & 8.72 & 4.09 \\
\hline
\end{tabular}

Refer Table 1 for the abbreviations.

\section{REPRODUCTIVE AND YIELD ATTRIBUTING CHARACTERS}

\section{Number of days to first flowering}

In the first experiment, the treatment didn't differ significantly regarding number of days to first flowering but numerically the highest number of days to first flowering (48.75 days) was recorded with inorganic fertilizers alone application (Table 3).

In the second experiment, application of NPK chemicals took the highest number of days to first flowering with (60 days) followed by vermicompost $100 \%$ (57.67 days), goat manure 50\% + urea 50\% (57.67 days) and FYM 100\% (57.33 days), all of them being at par with one another whereas FYM 50\% + urea $50 \%$ took the least number of days to first flowering (49.67 days) (Table 3). Naik (2005) reported that delayed flowering was recorded in treatments supplying $100 \%$ nitrogen through 
urea.Further data could not be recorded from the first experiment because of adverse weather condition.

\section{Per cent fruit set}

In the second experiment, per cent fruit set was the highest (45.66\%) with FYM $50 \%$ + urea $50 \%$ followed by FYM $100 \%$ (38.48\%) and goat manure $100 \%$ (35.14\%), all of them being at par with one another whereas per cent fruit set with goat manure 50\% + urea 50\% (31.84\%), vermicompost 100\% (29.79\%) and vermicompost $50 \%+$ urea $50 \%$ (29.7\%) were less (Table 3 ). Lower percent fruit set with the application of vermicompost $50 \%$ + urea $50 \%$ and goat manure $50 \%+$ urea $50 \%$ may be due to more availability of nitrogen at the time of flowering as the plot was top dressed with urea 30 days after transplanting of seedlings and more release of nitrogen from slow nutrient releasing organic manure at later stage of crop growth. Hassan et al. (1993) reported that fruit set per plant in pepper significantly decreased (35\%) as $N$ rates were increased from $112 \mathrm{~kg} / \mathrm{ha}$ to 488 $\mathrm{kg} / \mathrm{ha}$. A similar result was found with tomato (Garrison et al., 1967).

\section{Fruit length, diameter and weight}

Fruit length was the highest $(8.92 \mathrm{~cm})$ with FYM $50 \%+$ urea $50 \%$ followed by vermicompost $100 \%(8.65 \mathrm{~cm})$ and vermicompost $50 \%+$ urea $50 \%(8.5 \mathrm{~cm})$, all of them being at par. Other treatments exhibited shorter fruit length (Table 3 ). The treatments did not differ with respect to fruit diameter.

Table 3. Effect of different organic manures and their combination with urea on days to first flowering, per cent fruit set, fruit length, diameter and weight of sweet pepper var. California Wonder

\begin{tabular}{lllllll}
\hline Treatments & \multicolumn{2}{l}{ Days to first flowering } & $\begin{array}{l}\text { Per cent fruit } \\
\text { set }\end{array}$ & $\begin{array}{l}\text { Fruit length } \\
(\mathrm{cm})\end{array}$ & $\begin{array}{l}\text { Fruit } \\
\text { diameter } \\
(\mathrm{cm})\end{array}$ & $\begin{array}{l}\text { Weight (g } \\
\text { fruit-1) }\end{array}$ \\
\cline { 2 - 6 } FYM100\% & 1st Exp. & 2nd Exp. & & & & \\
\cline { 2 - 6 } FYM50\%+urea50\% & 47.25 & $57.33 \mathrm{a}$ & $44.221 \mathrm{a}$ & $7.073 \mathrm{c}$ & 6.380 & $83.82 \mathrm{bc}$ \\
GM100\% & 45.25 & $49.67 \mathrm{c}$ & $45.663 \mathrm{a}$ & $8.920 \mathrm{a}$ & 5.770 & $98.30 \mathrm{a}$ \\
GM50\%+urea50\% & 49.75 & $51.33 \mathrm{bc}$ & $35.138 \mathrm{ab}$ & $8.330 \mathrm{ab}$ & 5.910 & $90.89 \mathrm{ab}$ \\
VC 100\% & 48.25 & $57.67 \mathrm{a}$ & $31.843 \mathrm{~b}$ & $6.950 \mathrm{c}$ & 6.923 & $81.04 \mathrm{~cd}$ \\
VC 50\%+urea50\% & 48.25 & $57.67 \mathrm{a}$ & $29.786 \mathrm{~b}$ & $8.657 \mathrm{a}$ & 5.563 & $94.52 \mathrm{a}$ \\
NPKchemicals & 46.00 & $55.67 \mathrm{ab}$ & $29.703 \mathrm{~b}$ & $8.503 \mathrm{a}$ & 5.063 & $84.30 \mathrm{bc}$ \\
LSD(P=0.05) & 48.75 & $60.00 \mathrm{a}$ & $38.483 \mathrm{ab}$ & $7.280 \mathrm{bc}$ & 6.123 & $75.42 \mathrm{~d}$ \\
SEm & $\mathrm{ns}$ & $5.292^{*}$ & $10.87^{*}$ & $1.097^{* *}$ & $\mathrm{~ns}$ & $7.47^{* *}$ \\
CV\% & 1.032 & 1.717 & 3.527 & 0.355 & 0.411 & 2.424 \\
\hline & 4.33 & 5.35 & 16.78 & 7.74 & 11.94 & 4.83 \\
\hline
\end{tabular}

Refer Table 1 for the abbreviations. 
Weight per fruit was the greatest $(98.30$ g) with FYM $50 \%+$ urea $50 \%$ followed by vermicompost $100 \%(94.52 \mathrm{~g})$ and goat manure $100 \%(90.89 \mathrm{~g})$, these treatments being at par with one another whereas it was the lowest $(75.42 \mathrm{~g})$ with NPK chemicals. It is observed (Table 3 ) that combination of organic and inorganic fertilizers produced more weighty fruits than sole application of either in case of FYM but in case of goat manure and vermicompost it was reverse. This may be due to lower availability of nitrogen during early stage of growth of the crop as vermicompost and goat manure have slow nutrient releasing rate than FYM (Chaoui et al., 2003; Kirchman and Petterson, 1995). The slower nutrient release rate of vermicompost is due to its structure which is similar to slow release granule having an organic matter core and a clay casing (Shipitalo and Protz, 1989). Hassan et al. (1993) also found that improved $N$ availability during early stage of growth increased pepper fruit size. Moreover, Wiedenfeld (1986) reported that weight per fruit of bell pepper was heavier with basal application of total nitrogen than split application when slow releasing $N$ fertilizers were applied.

\section{YIELD AND QUALITY}

\section{Fruit yield}

Fruit yield was the highest (13.53 t/ha) with application of FYM $50 \%+$ urea $50 \%$ followed by goat manure 100\% (11.95 t/ha), both being at par with each other whereas with vermicompost $100 \%$, it was the lowest $(8.07 \mathrm{t} / \mathrm{ha})$ (Table 4$)$. The reason behind the highest yield obtained with the application of FYM $50 \%$ + urea $50 \%$ is due to the highest percent fruit set and the highest fruit weight with the application of same treatment. Though the weight per fruit was the highest with the application of vermicompost $100 \%$ due to the lowest per cent fruit set, the yield obtained was the lowest with that treatment. The Table 3 also indicates that the combination of organic manures and urea produced better yield for FYM and vermicompost than sole application of either. But it was reverse in case of goat manure. This may be due to lower weight per fruit produced with the application of goat manure $50 \%$ + urea $50 \%$ than goat manure $100 \%$. This result is similar to the findings of Nair and Peter (1990), who also found that application of both organic (FYM $15 \mathrm{t} / \mathrm{ha}$ ) and inorganic fertilizers (175 Kg N per ha) increased fruit yield.

\section{Physiological weight loss}

Physiological weight loss of the fruits obtained from the application of NPK chemicals was the highest (16.44\%) whereas with the application of goat manure $100 \%$ it was the lowest $(6.66 \%)$ followed by goat manure $50 \%+$ urea $50 \%(6.99 \%)$ (Table 4). Naik (2005) reported that maximum per cent physiological loss in weight was recorded with $100 \% \mathrm{~N}$ through urea.

\section{Vitamin C content}

Numerical values of Vitamin C content were the highest with goat manure $50 \%+$ urea $50 \%(52.43 \mathrm{mg} / 100 \mathrm{~g})$ followed by vermicompost $100 \%(51.53 \mathrm{mg} / 100 \mathrm{~g})$ and goat manure $100 \%$ (51.07 mg/100g). The lowest value was recorded with FYM $50 \%$ 
+ urea $50 \%$ (30.36 mg/100g) followed by NPK chemicals application (32.02 $\mathrm{mg} / 100 \mathrm{~g}$ ) (Table 4). Naik (2005) also reported that vitamin C content was the lowest with the application of $100 \% \mathrm{~N}$ through urea than with other combinations of organic manures.

\section{Benefit cost ratio}

Financial analysis (Table 4) revealed that FYM $50 \%+$ urea 50\% was superior of other treatments with respect to net profit and benefit cost ratio (5.32) followed by goat manure 100\% (4.41) and goat manure 50\% + urea 50\% (3.94). The lowest B: $\mathrm{C}$ ratio was found with vermicompost $100 \%(1.09)$. The least $\mathrm{B}$ : $\mathrm{C}$ ratio with the application of vermicompost $100 \%$ is due to highest price of vermicompost among all organic manures used in the experiment.

Table 4. Effect of different organic manures and their combination with urea on yield/ha, physiological weight loss, vitamin C content and B: C ratio of sweet pepper var. California Wonder at Nagarkot-1, Bhaktapur, 2011

\begin{tabular}{lllll}
\hline Treatments & $\begin{array}{l}\text { Yield } \\
\text { (ton/ha) }\end{array}$ & $\begin{array}{l}\text { Physiological weight } \\
\text { loss (\%) }\end{array}$ & $\begin{array}{l}\text { Vitamin C } \\
\text { (mg/100 g) }\end{array}$ & B:C ratio \\
\hline FYM100\% & $9.37 \mathrm{bc}$ & $9.54 \mathrm{~b}$ & 38.02 & 3.48 \\
FYM50\%+urea50\% & $13.53 \mathrm{a}$ & $8.13 \mathrm{bc}$ & 30.36 & 5.32 \\
GM100\% & $11.95 \mathrm{a}$ & $6.66 \mathrm{c}$ & 51.07 & 4.41 \\
GM50\%+urea50\% & $10.06 \mathrm{~b}$ & $6.99 \mathrm{c}$ & 52.43 & 3.94 \\
VC 100\% & $8.07 \mathrm{c}$ & $7.86 \mathrm{bc}$ & 51.53 & 1.09 \\
VC 50\%+urea50\% & $9.90 \mathrm{bc}$ & $7.46 \mathrm{bc}$ & 37.46 & 2.02 \\
NPKchemicals & $8.46 \mathrm{bc}$ & $16.44 \mathrm{a}$ & 32.90 & 3.27 \\
\hline LSD(P=0.05) & $1.71^{* *}$ & $2.207^{\text {** }}$ & & \\
SEm & 0.555 & 0.716 & & \\
CV\% & 9.43 & 13.76 & & \\
\hline
\end{tabular}

Refer Table 1 for the abbreviations.

\section{CONCLUSIONS}

The present study showed that the application of FYM 50\% + urea $50 \%$ resulted into the highest vegetative growth, yield and B: C ratio. The application of vermicompost, sole or in $50 \%$ combination with urea produced lower yield with lower B: C ratio. Thus, from this study it can be concluded that in mid hills of Nepal where the small farmers have less convenience to chemical fertilizers can replace urea by farm yard manure to fulfill half dose of nitrogen for obtaining better yield of sweet pepper and higher net profit as well.

\section{ACKNOWLEDGEMENT}

The authors are highly thankful to the Sustainable Soil Management Program (SSMP) for providing financial support for the preparation of this thesis and Directorate of Research, IAAS that enabled to undertake this research activity. 


\section{REFERENCES}

Bokhtiar, S. M., Paul G. C., \& Alam, K. M. (2008). Effects of organic and inorganic fertilizer on growth, yield, and juice quality and residual effects on ratoon crops of sugarcane.Journal of Plant Nutrition,31(10): 1832 - 1843.

CBS, (2010). Nepal vegetable crop survey 2009/10: A statistical report. Central Bureau of Statistics, National Planning Comission Secretariat. Government of Nepal. Nepal.

Chaoui, I. H., Zibilske, L. M., \& Ohno, S. (2003). Effect of earthworm casts and compost on microbial activity and plant nutrient uptake. Soil Biology and Biochemistry,35: 295302.

Damke, M. M., Kawarkhe, V. J., and Patil, C. O. (1988). Effect of phosphorus and potassium on growth and yield of chilli. Punjabrao Krishi Vidyapeeth Research Journal,12: 110114.

Deore, G. B., Limaye, A. S., Shinde, B. M., \& Laware, S. L. (2010). Effect of novel organic liquid fertilizer on growth and yield in chilli (Capsicum annum L.).Asian Journal of Exp Biological Science spl,2010: 15-19.

FAO, (2011). Food and Agriculture Organization Statistics Division. Available: http://faostat.fao.org/ [Retrived: August 9, 2011].

Garrison, S. A., Taylor, C. A., and Drinkwater, W. O. (1967). The influence of nitrogen nutrition on flowering, fruit set and yield of processing tomatoes. American Journal of Society of Horticultural Science, 91: 534-543.

Hassan, S. A., Gerber J. M., \& Splittstoesser, W. E. (1993). Growth and yield potential of green pepper as affected by nitrogen at transplanting. Pertanika Journal of Tropical Agricultural Science, 16(2): 101-105.

Kirchman, H., and Petterson, S. (1995). Human urine chemical composition and fertilizer use efficiency. Fertilizer Research,40: 149-154.

Naik, K. R. (2005). Influence of N-substitution levels through organic and inorganic sources on growth, yield and post harvest quality of capsicum under protected condition. Unpublished Ph.D thesis. University of Agriculture Science, Dharwad, India.

Nair, M., and Peter, K.V. (1990). Organic, inorganic fertilizers and their combinations on yield and storage life of hot chillies. Vegetable Science, 17: 7-10.

Renuka, B., and Ravisankar, C. (2001). Effect of organic manures on growth and yield of tomato. South Indian Horticulture, 49: 216-219.

Sunitha, T. R. (2007). Insect pests of Capsicum annuum var. Frutescens and their management. M. Sc. Ag. Thesis. University of agricultural sciences, Dharwad.

Shipitalo, M. J., and Protz, R. (1989). Chemistry and micro morphology of aggregation in earthworm cast. Geoderma,45: 357-374.

Surlekov, P., and Rankov. (1989). The effect of fertilization on capsicum productivity and soil agro-chemical and biological properties in monoculture: 46-52.

Wiedenfeld, R. P. (1986). Rate, timing, and slow release nitrogen fertilizer on bell pepper and musk melon. Horticulture Science, 21: 233-235. 